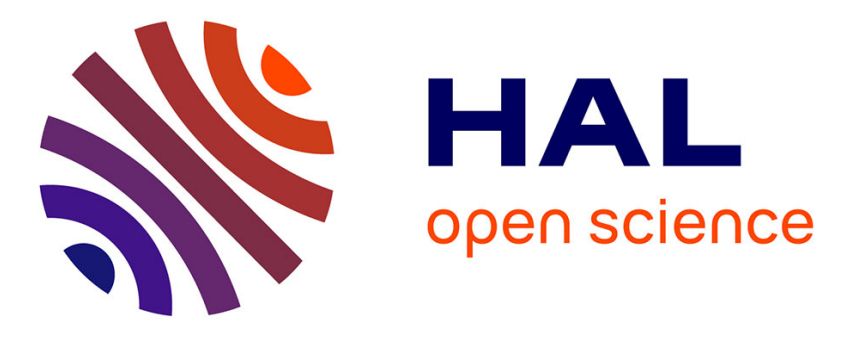

\title{
Trace Element Concentrations in Relation to the Trophic Behaviour of Endangered Ivory Gulls (Pagophila eburnea) During Their Stay at a Breeding Site in Svalbard \\ Magali Lucia, Hallvard Strøm, Paco Bustamante, Geir W Gabrielsen
}

\section{To cite this version:}

Magali Lucia, Hallvard Strøm, Paco Bustamante, Geir W Gabrielsen. Trace Element Concentrations in Relation to the Trophic Behaviour of Endangered Ivory Gulls (Pagophila eburnea) During Their Stay at a Breeding Site in Svalbard. Archives of Environmental Contamination and Toxicology, 2016, 71, pp.518 - 529. 10.1007/s00244-016-0320-6 . hal-01423281

\section{HAL Id: hal-01423281 \\ https://hal.science/hal-01423281}

Submitted on 29 Dec 2016

HAL is a multi-disciplinary open access archive for the deposit and dissemination of scientific research documents, whether they are published or not. The documents may come from teaching and research institutions in France or abroad, or from public or private research centers.
L'archive ouverte pluridisciplinaire HAL, est destinée au dépôt et à la diffusion de documents scientifiques de niveau recherche, publiés ou non, émanant des établissements d'enseignement et de recherche français ou étrangers, des laboratoires publics ou privés. 


\title{
Trace Element Concentrations in Relation to the Trophic Behaviour of Endangered Ivory Gulls (Pagophila eburnea) During Their Stay at a Breeding Site in Svalbard
}

\author{
Magali Lucia ${ }^{1 *}$, Hallvard Strøm ${ }^{1}$, Paco Bustamante ${ }^{2}$, Geir W. Gabrielsen ${ }^{1}$ \\ ${ }^{1}$ Norwegian Polar Institute, FRAM High North Research Centre for Climate and the Environment, \\ Postbox 6606 Langnes, 9296 Tromsø, Norway \\ ${ }^{2}$ Littoral, Environnement et Sociétés (LIENSs), UMR 7266 CNRS-Université de La Rochelle, 2 \\ rue Olympe de Gouges, 17000 La Rochelle, France. \\ *Corresponding author: Magali LUCIA \\ Email: magali.lucia@npolar.no \\ Address: Norwegian Polar Institute, Fram Centre \\ Postbox 6606 Langnes \\ 9296 Troms $\varnothing$, Norway \\ Telephone: (+47) 77750500 \\ Fax: (+47) 77750501
}




\begin{abstract}
The ivory gull is a high-Arctic species considered endangered in most parts of its breeding range. Ivory gulls must cope with both the reduction of sea ice cover triggered by climate change and increasing contaminant loads due to changes in global contaminant pathways. The objective of this study was to assess the concentration of 14 essential and non-essential trace elements at four colonies of ivory gulls breeding on Barentsøya, Svalbard, and the relationship between contaminant exposure and the diet of individuals. Contaminants and stable isotopes $\left(\delta^{15} \mathrm{~N}\right.$, $\delta^{13} \mathrm{C}$ ) were determined in blood (red blood cells and whole blood), and feathers of ivory gulls collected over several years. The most quantitatively abundant non-essential trace element found in the ivory gull was mercury $(\mathrm{Hg})$. Selenium $(\mathrm{Se})$ was present in substantial surplus compared with $\mathrm{Hg}$, which would imply relative protection against $\mathrm{Hg}$ toxic effects but raises concern about Se potential toxicity. Moreover, other elements were detected, such as silver, arsenic, cadmium, and lead, which would warrant monitoring because of the potential additive/synergetic effects of these compounds. This study demonstrated individual differences in trophic behaviour that triggered discrepancies in $\mathrm{Hg}$ concentrations, highlighting the potential biomagnifying ability of this metal in the ivory gull's food web. Results highlighted the mixing of birds coming from different geographical areas on Barentsøya.
\end{abstract}

Keywords: Ivory gull, Seabird, Mercury, Metal, Arctic, Stable Isotopes 


\section{Introduction}

Among trace elements, some are categorized as non-essential, such as silver (Ag), cadmium (Cd), lead $(\mathrm{Pb})$, and mercury $(\mathrm{Hg})$, whereas others are considered nutritionally essential, such as arsenic (As), cobalt $(\mathrm{Co})$, chromium $(\mathrm{Cr})$, copper $(\mathrm{Cu})$, iron $(\mathrm{Fe})$, manganese $(\mathrm{Mn})$, nickel $(\mathrm{Ni})$, selenium $(\mathrm{Se})$, vanadium $(\mathrm{V})$, and zinc $(\mathrm{Zn})$. However essential, all of these trace elements can become toxic at high exposure levels.

Seabirds can bioaccumulate high contaminant levels due to their wide distribution, long life-span, and high position in the food chain (Hobson et al. 2002). These top-predators are affected by biomagnification processes of a variety of elements (e.g., $\mathrm{Hg}$ ) with concentrations consistently increasing from lower to higher trophic levels where several studies observed sublethal and/or lethal concentrations and adverse effects (Gibson et al. 2014; Goutte et al. 2014a, b). One of the main goals in ecotoxicology is to examine more precisely the trophic ecology of species to better understand exposure pathways and explain contaminant concentrations in animal populations. In this context, carbon and nitrogen stable isotopes have become a powerful tool to investigate trophic relationships and/or origins of prey to elucidate broad-scale, inter-, and intraspecific dietary patterns. Consequently, studies in this field allow investigating whether differences in foraging strategies can explain variations in contaminant uptake (Jardine et al. 2006).

The ivory gull (Pagophila eburnea) is a high-Arctic species spending the entire year in the north closely associated with sea ice. Three main wintering grounds were identified for northeast Atlantic populations (north Greenland, Svalbard, and Franz Josef Land) of this long distant migrant species in southeast Greenland, along the Labrador sea-ice edge and the Bering Strait region (Gilg et al. 2010; Spencer et al. 2014). The species is listed as "Near Threatened” by the International Union for Conservation of Nature and considered endangered in most part of its breeding range. This ivory gull is especially endangered in Canada, where numbers have declined by $80-85 \%$ since the 1980s (Gilchrist and Mallory 2005). Nevertheless, it is one of the world's most poorly known species even though its high position in the marine food web makes it sensitive to contaminant exposure (Karnovsky et al. 2009). The ivory gull is indeed known to feed mainly on polar cods (Boreogadus saida) and crustaceans associated with the ice edge or to scavenge remains of polar bear kills (Mehlum 1990; Mehlum and Gabrielsen 1993; Karnovsky et al. 2009). Bond et al. (2015) suggested that the population decline observed in the Canadian Arctic may be linked partly to declines in reproduction success from increased exposure to $\mathrm{Hg}$ and its methylated form $(\mathrm{MeHg})$. 
Previous studies also demonstrated high exposure to organic contaminants along the distribution range of the ivory gull (Braune et al. 2007; Miljeteig et al. 2009; Lucia et al. 2015). However, apart from $\mathrm{Hg}$, nothing is known about the exposure to trace elements of this free-ranging Arctic species. The purpose of the present study was to examine concentrations of essential and non-essential trace elements ( $\mathrm{Ag}, \mathrm{As}, \mathrm{Cd}, \mathrm{Co}, \mathrm{Cr}, \mathrm{Cu}, \mathrm{Fe}, \mathrm{Hg}, \mathrm{Mn}, \mathrm{Ni}, \mathrm{Pb}, \mathrm{Se}, \mathrm{V}$, and $\mathrm{Zn}$ ) at four colonies of ivory gulls breeding on Barentsøya, Svalbard, and the relationship between contaminant exposure and the diet of individuals. Trace elements were determined in blood (red blood cells or whole blood depending on the year) and ventral feathers of ivory gulls collected between 2011 and 2014. In parallel, carbon and nitrogen stable isotopes were determined on the same tissues to investigate the foraging ecology during both breeding and moulting periods, which are greatly overlapping in the ivory gull presumably due to the constraints of its high-latitude winter range and the brief Arctic summer (Howell 2001). In this species, adults have only a single moult per cycle. Nevertheless, exposure and diets between breeding and moulting can be dissociated due to the fact that the moult is mostly completed before the prelaying to hatching period (mid June to early August).

\section{Materials and methods}

\section{Sample collection and preparation}

Ivory gulls were collected for blood and ventral feathers between 2011 and 2014 at four breeding colonies (Auga, Freemanbreen, Hübnerbreen, Sigden, Fig. 1) on Barentsøya, Svalbard, and along the ice edge in Spring (April). Birds were caught by the use of a single-catch closing net trap baited with a small piece of seal blubber. Blood was sampled from the brachial vein. When it was possible, sex was determined through DNA analysis, as well as morphometric measurements (e.g., mass). Overall, whole blood was sampled for isotope analyses and trace element determination in 2011 (n =6), $2012(\mathrm{n}=4)$, and $2013(\mathrm{n}=5)$, whereas red blood cells (erythrocytes) were obtained after centrifugation in the field (4000 rpm, $10 \mathrm{~min})$ in $2013(\mathrm{n}=40)$ and $2014(\mathrm{n}=42)$. Ventral feathers were sampled in $2011(n=19), 2012(n=40), 2013(n=47)$, and $2014(n=39)$. Over the years, red blood cells were sampled in four colonies: Auga $(n=5)$, Freemanbreen $(n=24)$, Hübnerbreen $(\mathrm{n}=20)$, Sigden $(\mathrm{n}=28)$, whole blood in two colonies: Freemanbreen $(\mathrm{n}=7)$, Hübnerbreen $(\mathrm{n}=$ $2)$, and the ice edge $(n=5)$, and feathers in four colonies: Auga $(n=5)$, Freemanbreen $(n=70)$, Hübnerbreen $(n=31)$, Sigden $(n=30)$, and the ice edge $(n=8)$. All the blood samples were stored at $-20^{\circ} \mathrm{C}$ until further analyses. Blood samples were later freeze-dried, then grounded and stored 
in individual plastic vials until further trace element and isotopic analyses. Ventral feathers were washed to remove oil and dirt in a chloroform-methanol solution (2:1) in an ultrasonic bath for 2 min. Afterwards, they were rinsed in two consecutive pure methanol baths for a few seconds and dried at $40{ }^{\circ} \mathrm{C}$ for $48 \mathrm{~h}$.

\section{Trace element determination}

Analyses were performed at the UMR 7266 CNRS Université de La Rochelle in France. Total Hg analyses were performed with an Advanced Mercury Analyser (ALTEC AMA 254), on dried tissue aliquots ranging from 1 to $20 \mathrm{mg}$, weighed to the nearest $0.01 \mathrm{mg}$. For $\mathrm{Hg}$ determination, the metal was evaporated by progressive heating up to $800^{\circ} \mathrm{C}$, then held under oxygen atmosphere for $3 \mathrm{~min}$, and finally amalgamated on a gold net. Afterwards, the net was heated to liberate the collected $\mathrm{Hg}$, which was measured by atomic absorption spectrophotometry. Mercury analyses were run according to a thorough quality control program, including the analysis of a NRC reference material (lobster hepatopancreas TORT-2; National Research Council, Canada). Standard aliquots were treated and analysed according to the same conditions as the samples. Results were in good agreement with certified values, with a mean recovery rate of $98 \%$. The detection limit was $5 \mathrm{ng}$ $\mathrm{Hg} \mathrm{g}^{-1}$ dry weight (dw).

$\mathrm{Ag}, \mathrm{As}, \mathrm{Cd}, \mathrm{Co}, \mathrm{Cr}, \mathrm{Cu}, \mathrm{Fe}, \mathrm{Mn}, \mathrm{Ni}, \mathrm{Pb}, \mathrm{Se}, \mathrm{V}$, and $\mathrm{Zn}$ were analysed using a Varian Vista-Pro ICP-OES and a ThermoFisherScientific XSeries 2 ICP-MS. Aliquots of the biological samples (20$200 \mathrm{mg}$ ) were digested with $6 \mathrm{ml} 67-70 \% \mathrm{HNO}_{3}$ and $2 \mathrm{ml} \mathrm{34-37 \%} \mathrm{HCl}$ (Fisher Scientific, trace element grade quality) (except for feathers: $3 \mathrm{ml} \mathrm{HNO}_{3}$ and $1 \mathrm{ml} \mathrm{HCl}$ ). Acidic digestion of samples was performed overnight at room temperature, then using a Milestone microwave (30 min with constantly increasing temperature up to $120^{\circ} \mathrm{C}$, then $15 \mathrm{~min}$ at this maximal temperature). Each sample was completed to $50 \mathrm{ml}$ (or $25 \mathrm{ml}$ for feathers) with milli-Q water. Three control samples (two Certified Reference Materials, CRMs, and one blank) treated and analysed in the same way as the samples were included in each analytical batch. CRMs were dogfish liver DOLT-4 (NRCC) and lobster hepatopancreas TORT-2 (NRCC). Quantification limits and mean recovery rates were, respectively, equal to $0.1 \mu \mathrm{g} \mathrm{L}^{-1}$ and $77 \%$ for $\mathrm{Ag}, 1 \mu \mathrm{g} \mathrm{L}^{-1}$ and $96 \%$ for As, $0.1 \mu \mathrm{g} \mathrm{L}^{-1}$ and $100 \%$ for $\mathrm{Cd}, 0.1 \mu \mathrm{g} \mathrm{L}^{-1}$ and $98 \%$ for $\mathrm{Co}, 0.1 \mu \mathrm{g} \mathrm{L}^{-1}$ and $97 \%$ for $\mathrm{Cr}, 0.5 \mu \mathrm{g} \mathrm{L}^{-1}$ and $94 \%$ for $\mathrm{Cu}, 20 \mu \mathrm{g}$ $\mathrm{L}^{-1}$ and $90 \%$ for Fe, $0.5 \mu \mathrm{g} \mathrm{L}^{-1}$ and $91 \%$ for $\mathrm{Mn}, 0.2 \mu \mathrm{g} \mathrm{L}^{-1}$ and $98 \%$ for $\mathrm{Ni}, 0.1 \mu \mathrm{g} \mathrm{L}^{-1}$ and $94 \%$ for 
$\mathrm{Pb}, 0.5 \mu \mathrm{g} \mathrm{L}^{-1}$ and $97 \%$ for Se, $2 \mu \mathrm{g} \mathrm{L}^{-1}$ and $97 \%$ for $\mathrm{V}$, and $20 \mu \mathrm{g} \mathrm{L}^{-1}$ and $102 \%$ for $\mathrm{Zn}$. Trace element concentrations are expressed in $\mu \mathrm{g} \mathrm{g}^{-1} \mathrm{dw}$.

\section{Nitrogen and carbon stable isotope analysis}

Depending on birds and years, stable isotopes were determined in ventral feathers and, either on the whole blood or red blood cells (see above). Analyses were performed at the UMR 7266 CNRSUniversité de La Rochelle in France. Cleaned feathers of ivory gulls were finely chopped using stainless steel surgical scissors and accurately weighed $( \pm 0.001 \mathrm{mg})$ to a range between 0.1 and $0.4 \mathrm{mg}$. Blood samples were also weighed with the same accuracy and in the same range of masses. All samples were placed in tin capsules for carbon and nitrogen stable isotope analysis and analysed using an elemental analyser (Flash EA 1112 fitted with a "No Blank" option, Thermo Scientific, Milan, Italy) coupled to an isotope ratio mass spectrometer (Delta V Advantage, Conflo IV interface, Smart EA option, Thermo Scientific, Bremen, Germany). Results are reported in $\delta$ unit notation (expressed in per mil relative to standards: Vienna Pee Dee Belemnite for $\delta^{13} \mathrm{C}$ and $\mathrm{N}_{2}$ in air for $\delta^{15} \mathrm{~N}$ ). The analytical precision of the measurements was $<0.06 \%$ and $<0.1 \%$ for carbon and nitrogen, respectively.

\section{Data treatment and statistical analyses}

Several compounds that were detected or analysed in less than $60 \%$ of the samples were excluded from statistical analyses including As, $\mathrm{Cr}$, and V for feathers, $\mathrm{Ag}, \mathrm{Co}, \mathrm{Cr}, \mathrm{Ni}$ and $\mathrm{V}$ for red blood cells, and $\mathrm{Ag}, \mathrm{Cd}, \mathrm{Co}, \mathrm{Cr}, \mathrm{Ni}, \mathrm{V}$ for the whole blood. Values below the quantification limit were taken into account in calculation of the means by assigning those values one-half of the detection limit for the given contaminant (e.g. a value $<0.02 \mathrm{ng} \mathrm{g}^{-1} \mathrm{dw}_{\text {was }}$ reported as $0.01 \mathrm{ng} \mathrm{g}^{-1} \mathrm{dw}$ ).

As normality and homogeneity of variance were not achieved despite $\log _{10}(\mathrm{x}+1)$ transformation (Cochran $C$ test), non-parametric analysis of variance (Kruskal-Wallis and Mann-Whitney $U$-test) was applied to assess differences in contaminant concentrations for each parameters (e.g. tissue, colony, year, sex). Moreover, the Spearman test was applied to all correlations achieved in this study.

Principal Component Analysis (PCA) was used to identify trends in the distribution of trace element concentrations among individuals collected. Each trace element concentration was first 
normalized (mean was subtracted and the difference was then divided by the standard deviation). Four separate analyses were performed to investigate the distribution of individuals in regards of two factors: the year and the colony, and using in both cases feather and red blood cell data. These analyses were performed using the PERMANOVA + package (Anderson et al., 2008) from PRIMER v6 (Clarke and Gorley 2006).

\section{Results}

\section{Trace element concentrations in tissues}

Mean concentrations and ranges of the 14 trace elements in feathers, whole blood and red blood cells of the ivory gull are presented in Tables 1 and 2 for non-essential and essential elements, respectively. In general, trace element concentrations strongly varied between tissues. Most nonessential element concentrations were low, especially for $\mathrm{Ag}, \mathrm{Cd}$ and $\mathrm{Pb}$ (Table 1). Concentrations in feathers were however mainly above detection limits. Mercury reached high mean concentrations, ranging between $0.81 \pm 0.05 \mu \mathrm{g} \mathrm{g}^{-1} \mathrm{dw}$ in the whole blood and $3.39 \pm 0.30 \mu \mathrm{g} \mathrm{g}^{-1}$ $\mathrm{dw}$ in feathers. In the latter tissue, $\mathrm{Hg}$ concentrations ranged between 0.41 and $14.8 \mu \mathrm{g} \mathrm{g}^{-1} \mathrm{dw}$, and $13 \%$ of the individuals displayed concentrations above $5 \mu \mathrm{g} \mathrm{g}^{-1} \mathrm{dw}$. Differences between tissues were analysed taking into account birds which have been sampled for both blood and feathers. All year combined, $\mathrm{Hg}$ concentrations in the blood were significantly lower than in feathers (MannWhitney test, $p<0.01)$. Concentrations of $\mathrm{Cd}$ were also significantly higher in feathers compared to red blood cells (Mann-Whitney test, $\mathrm{p}<0.001$ ). In parallel, $\mathrm{Cd}$ concentrations in both tissues were positively correlated ( $r=0.49$; Spearman correlation test, $p<0.05$ ). Lead concentrations, however, were higher in red blood cells due to the high levels reached in $2014\left(0.70 \pm 0.13 \mu \mathrm{g} \mathrm{g}^{-1}\right.$ $\mathrm{dw}$ ). To exclude year as confounding factor, red blood cells and feathers were compared in 2013 only. Lead concentrations in red blood cells were subsequently lower than in feathers $(p<0.001)$. Similarly, Pb concentrations in the whole blood, determined between 2011 and 2013, were lower than in feathers (Mann-Whitney test, $p<0.001$ ). Lead concentrations in feathers and red blood cells were, as for $\mathrm{Cd}$, positively correlated $(r=0.47$; Spearman correlation test, $p<0.05)$. Finally, no correlations were observed between feathers and whole blood concentrations for all the elements studied.

For essential trace elements, $\mathrm{Co}, \mathrm{Cr}$ and $\mathrm{Ni}$ concentrations were low in all tissues (Table 2). Vanadium was always below quantification limits. Arsenic in feathers was also below 
quantification limits, whereas higher mean concentrations were found in the blood. Mean concentrations were indeed comprised between $3.76 \pm 0.56 \mu \mathrm{g} \mathrm{g}^{-1} \mathrm{dw}$ in the whole blood in 2011 and $5.27 \pm 0.60 \mu \mathrm{g} \mathrm{g}^{-1} \mathrm{dw}$ in red blood cells in 2013. Two other elements, Fe and Se, displayed higher blood concentrations than in feathers (Table 2). Both elements had however their feather concentrations positively and significantly correlated to their respective blood concentrations (Fe: $\mathrm{r}=0.41$, Se: $\mathrm{r}=0.53$; Spearman correlation test, $p<0.05$ ). Conversely, $\mathrm{Cu}$ concentrations were significantly higher in feathers than in blood. Depending on the year, mean feather concentrations ranged between $16.5 \pm 0.39$ and $17.9 \pm 0.35 \mu \mathrm{g} \mathrm{g}^{-1} \mathrm{dw}$, whereas mean whole blood and red blood cell concentrations were comprised between $0.99 \pm 0.02 \mu \mathrm{g} \mathrm{g}^{-1} \mathrm{dw}$ and $1.21 \pm 0.05 \mu \mathrm{g} \mathrm{g}^{-1} \mathrm{dw}$. The same pattern was observed for $\mathrm{Mn}$ and $\mathrm{Zn}$, which displayed significantly higher concentrations in feathers (Mann-Whitney test, $p<0.05$ ).

Numerous correlations were found between elements in all tissues (Table 3). Correlations between trace element concentrations appeared however to vary in regard of tissues, especially for feathers and red blood cells where the highest number of individuals were studied. Among the relationships between trace elements, $\mathrm{Cu}$ and Fe were positively correlated in feathers $(r=0.25)$ but negatively in red blood cells $(r=-0.51)$. Iron also was negatively correlated to $\mathrm{Pb}$ in red blood cells $(r=0.46)$. Mercury and Se were positively correlated in both feathers and red blood cells $(r$ $=0.22, r=0.28$, respectively; Table 3 ). The Se:Hg molar ratios were calculated in tissues of ivory gulls. The ratios always exceeded 1 for all the birds in the blood and ranged between 14 and 139. Ratios in feathers were considerably lower and ranged between 0.3 and 6.7 .

\section{Influence of the year, colony, sex, and body weight on trace element concentrations}

Several trace elements showed an increasing trend over the years (Tables 1 and 2). In feathers, this trend was observed for Ag, Cd in 2014, and even Mn and Se between 2011 and 2013. However, $\mathrm{Mn}$ and Se concentrations also demonstrated a decrease in 2014. In red blood cells, even if the data only represent two years of sampling, an increase in concentrations could be observed for $\mathrm{Cd}, \mathrm{Cu}$ and $\mathrm{Pb}$ between 2013 and 2014. Figure 2 presents PCAs performed on ivory gull data in feathers and red blood cells to identify trends in the distribution of trace elements between years. For feathers, the first 2 axes extracted 36.4\% of the variance of the data clouds (Figure 2A). The first axis (PC1) was positively correlated with $\mathrm{Co}, \mathrm{Fe}$ and $\mathrm{Mn}$, whereas the second axis (PC2) was positively correlated with $\mathrm{Cd}, \mathrm{Hg}$ and Se concentrations (Figure 2A). The projection of feather 
samples demonstrated that ivory gulls sampled in 2013 were characterized by slightly higher Co, Fe, and Mn concentrations. However, this trend only appeared for part of the birds sampled that year. Overall, differences between years were unclear in this tissue. Conversely, a PCA was performed with red blood cell data, even if this tissue was only collected in 2013 and 2014 (Figure 2B). The first axis (PC1) was positively correlated with $\mathrm{Fe}$ and negatively with $\mathrm{Cu}$ and $\mathrm{Pb}$, whereas the second axis (PC2) was negatively correlated with $\mathrm{Cd}, \mathrm{Mn}$ and $\mathrm{Zn}$ concentrations. The projection of red blood cell samples demonstrated a clear dichotomy between 2013 and 2014, both years being separated along the first axis even if individuals belonging to both years were scattered across the PCA. In 2013, birds were characterized by higher As, Fe, Hg and Se concentrations, whereas in 2014, birds displayed higher $\mathrm{Cu}$ and $\mathrm{Pb}$ concentrations. No PCA was realized on whole blood data because of the few birds sampled for this tissue.

Figure 3 presents PCAs performed on ivory gull data in feathers and red blood cells to identify trends in the distribution of trace elements between colonies and the ice edge. For feathers, the first 2 axes extracted $36.7 \%$ of the variance of the data clouds (Figure 3A). Overall, no clear tendencies and differences were observed between colonies. Another PCA was realized with red blood cell data (Figure 3B). The first axis (PC1) was negatively correlated with $\mathrm{Cu}$ and $\mathrm{Pb}$, whereas the second axis (PC2) was positively linked with Mn and Zn. Most of the birds were spread across the PCA with, as in feathers, unclear trends. Nevertheless, it should be noted that birds from Sigden, even if scattered across the graph, showed a tendency of higher $\mathrm{Cu}$ and $\mathrm{Pb}$ concentrations than in other colonies. Indeed, mean $\mathrm{Cu}$ concentration in Sigden reached $1.13 \pm 0.03 \mu \mathrm{g} \mathrm{g}^{-1} \mathrm{dw}$, and was significantly higher than in Auga $\left(0.95 \pm 0.01 \mu \mathrm{g} \mathrm{g}^{-1} \mathrm{dw}\right)$ and Hübnerbreen $\left(1.00 \pm 0.02 \mu \mathrm{g} \mathrm{g}^{-1} \mathrm{dw}\right.$; Kruskal-Wallis test, $p<0.05)$, but not than in Freemanbreen $\left(1.03 \pm 0.02 \mu \mathrm{g} \mathrm{g}^{-1} \mathrm{dw}\right)$. For Pb, Sigden concentration $\left(0.75 \pm 0.17 \mu \mathrm{g} \mathrm{g}^{-1} \mathrm{dw}\right)$ was significantly higher than both Hübnerbreen $(0.07 \pm 0.04$ $\left.\mu \mathrm{g} \mathrm{g}^{-1} \mathrm{dw}\right)$ and Freemanbreen $\left(0.22 \pm 0.11 \mu \mathrm{g} \mathrm{g}^{-1} \mathrm{dw}\right.$; Kruskal-Wallis test, $\left.p<0.05\right)$, but not significantly different to Auga $\left(0.38 \pm 0.21 \mu \mathrm{g} \mathrm{g}^{-1} \mathrm{dw}\right)$.

The sex of ivory gulls was successfully determined in 24 females and 65 males for feather samples, and 18 females and 30 males for red blood cell samples. The influence of sex was then investigated on both tissue concentrations. For the most part, no differences were observed between females and males. Even if differences were low, females displayed significantly higher Ag concentrations than male in feathers (female: $0.065 \pm 0.004$ vs male: $0.055 \pm 0.002 \mu \mathrm{g} \mathrm{g}^{-1} \mathrm{dw}$; Mann-Whitney test, 
$p=0.042$ ), and both Mn (female: $0.15 \pm 0.01$ vs male: $0.13 \pm 0.01 \mu \mathrm{g} \mathrm{g}^{-1} \mathrm{dw} ; p=0.023$ ) and $\mathrm{Zn}$ (female: $21.9 \pm 0.3$ vs male: $21.2 \pm 0.3 \mu \mathrm{g} \mathrm{g}^{-1} \mathrm{dw} ; p=0.033$ ) in red blood cells.

Finally, the relation between trace element concentrations and total body weight of birds was investigated. The body weight of ivory gulls was positively correlated with $\mathrm{Hg}$ concentrations in red blood cells $(r=0.28)$, and negatively with Mn concentrations in the whole blood ( $r=-0.63$; Spearman correlation test, $p<0.05$ ). No correlations appeared between feather concentrations and body weight of birds.

\section{Relationship between trophic position, feeding habitat and trace element concentrations}

The relation between the trophic behaviour, assessed through the determination of $\delta^{15} \mathrm{~N}$ and $\delta^{13} \mathrm{C}$, and trace element concentrations of ivory gulls was studied in three tissues: feathers, red blood cells and whole blood. Of all elements, $\mathrm{Hg}$ was positively correlated with $\delta^{15} \mathrm{~N}$ and $\delta^{13} \mathrm{C}$ in all tissues, with the exception of $\delta^{15} \mathrm{~N}$ in the whole blood $\left(\delta^{15} \mathrm{~N}\right.$ : $r_{\text {feathers }}=0.36, r_{\text {red blood cells }}=0.46 ; \delta^{13} \mathrm{C}$ : $r_{\text {feathers }}=0.51, r_{\text {red blood cells }}=0.50, r_{\text {whole blood }}=0.52$; Spearman correlation test, $p<0.05$; Figure 4 ). Figure 4 showed that one individual for both feathers and red blood cells presented high $\mathrm{Hg}$ and stable isotopes levels. These individuals, corresponding to two different birds for both tissues, could be identified as mostly responsible for the positive correlations observed. However, those correlations still appeared when these individuals were removed from analyses (data not shown). In red blood cells, other relationships were significant, such as positive correlations between $\delta^{13} \mathrm{C}$ and both $\mathrm{Fe}(r=0.40)$ and $\mathrm{Se}(r=0.25)$ concentrations, as well as negative correlations between $\delta^{13} \mathrm{C}$ and $\mathrm{Cd}(r=-0.32), \mathrm{Cu}(r=-0.29)$, and $\mathrm{Pb}(r=-0.35)$ concentrations. In feathers, $\delta^{13} \mathrm{C}$ was negatively linked with $\mathrm{Ag}(r=-0.29)$, whereas $\delta^{15} \mathrm{~N}$ was negatively correlated with $\mathrm{Ni}(r=-0.21)$. Finally, in the whole blood, the only correlations observed apart from $\mathrm{Hg}$, were between $\delta^{15} \mathrm{~N}$ and both $\mathrm{Mn}(r=0.54)$ and $\mathrm{Se}(r=-0.60)$.

\section{Discussion}

\section{Trace element concentrations and toxicology significance}

Although most trace elements occur naturally in the marine environment, they also are widely released through anthropogenic activities. Even if few of these activities are located in the Arctic, this region acts as a sink for contaminant produced in industrialized parts of the world and 
transported northward by air, sea, and water masses (Poissant et al. 2008). Moreover, in a changing environment, the Arctic is likely to be submitted to increasing anthropogenic pressure. As of today, few studies have focused on trace elements in Arctic seabirds (Braune and Scheuhammer 2008; $\varnothing$ verjordet et al. 2015). The present study allowed investigating trace element concentrations in one of the most poorly researched seabirds in the Northern hemisphere: the ivory gull. Overall, most of the elements studied were detected in this species, even if low elemental concentrations were mainly recorded.

Among elements with the highest levels, $\mathrm{Hg}$ is one of greatest concern in the Arctic environment because of its capacity to undergo long-range atmospheric transport and be deposited northwards. Polar regions act as sinks for $\mathrm{Hg}$ (Macdonald et al. 2005). Melting snow and ice allow the transfer of $\mathrm{Hg}$ to the marine environment and its biomagnification up the food chain (Campbell et al. 2005). In the ivory gull, Bond et al. (2015) demonstrated a clear increase in feather MeHg concentrations between 1877 and 2007 using museum specimens from the Canadian Arctic and western Greenland (from 0.09 to $4.11 \mu \mathrm{g} \mathrm{g}^{-1}$ in adults). These authors also reported total $\mathrm{Hg}$ concentrations reaching on average $3.84 \pm 2.02 \mu \mathrm{g} \mathrm{g}^{-1}$ in post-1975 years. Previous reports from studies examining the Arctic have shown an east-west increase of $\mathrm{Hg}$ egg concentrations of the ivory gull (Lucia et al. 2015). Those higher Hg concentrations in the Canadian Arctic were partly explained by naturally higher $\mathrm{Hg}$ levels in sediments from this region associated with the deposition of large amounts of anthropogenic $\mathrm{Hg}$ that originated from China (Muir et al. 1999; AMAP 2011). In the present study, ivory gull from Svalbard indeed displayed slightly lower concentrations than in the Canadian Arctic and western Greenland (Bond et al. 2015), reaching $3.39 \pm 0.30 \mu \mathrm{g} \mathrm{g}^{-1}$ in feathers in 2014. This concentration also was well below observed levels in ivory gull feathers collected in 2010 on Seymour Island, Canada, where the concentration was on average $11.66 \pm 5.52 \mu \mathrm{g} \mathrm{g}^{-1} \mathrm{dw}$. However, some individuals in the present study reached high $\mathrm{Hg}$ concentrations, exceeding $5 \mu \mathrm{g}$ $\mathrm{g}^{-1} \mathrm{dw}$ in feathers, threshold that would be indicative of body burdens of $\mathrm{Hg}$ that would have adverse effects (Burger and Gochfeld 1997a). Mercury is mainly accumulated as MeHg in feathers (Thompson and Furness 1989). Mallory et al. (2015) found that $\mathrm{MeHg}$ averaged 67-81\% of the total $\mathrm{Hg}$ in ivory gull feathers from the Canadian Arctic. Overall, these results suggest that $\mathrm{Hg}$ concentrations may be sufficiently elevated to trigger sublethal effects and/or reproduction impairments and consequently contribute to the population decline (Burgess and Meyer 2008; Bond et al. 2015). Nevertheless, $\mathrm{Hg}$ toxicity often is balanced by Se accumulation and the 
formation of $\mathrm{Hg}$-Se complexes. Both element concentrations were positively correlated in feathers and red blood cells of ivory gulls. Selenium is essential to organisms' metabolism but can also be toxic depending upon the chemical form ingested (Stewart et al. 1999). Both elements' chemical properties have therefore a key role in alleviating their respective toxicity at high exposure (Khan and Wang 2009). Mercury and Se were found to be positively linked in both feathers and red blood cells. Selenium toxic effects include reproductive impairments with teratogenesis, growth reduction, histopathological lesions, alterations in hepatic glutathione metabolism, and even direct mortality in some cases (Hoffman 2002). In blood samples of this study, Se was present in a substantial surplus compared with $\mathrm{Hg}$. Feather $\mathrm{Se}: \mathrm{Hg}$ ratio was on average $1.45 \pm 0.08$, therefore suggesting the presence of mercuric selenide, a well-known non-toxic form in marine mammals and birds (Ikemoto et al. 2004; Khan and Wang 2009). Overall, ivory gulls are presumably protected against $\mathrm{Hg}$ toxicity, but those results raise concern about Se toxicity to this species. Another interesting result was the detection of other trace elements, such as Ag (feathers), As (blood), $\mathrm{Cd}$, and $\mathrm{Pb}$. Although low emissions of $\mathrm{Cd}$ were recorded in the Arctic, other studies have found $\mathrm{Cd}$ bioaccumulation in Arctic seabirds (Øverjordet et al. 2015). The global anthropogenic emission of Cd exceeded natural emissions in the mid-1980s (AMAP 1997). However, Cd presence in the Arctic is thought to be linked to geochemical processes of the ocean and, therefore, mainly originating from natural emissions. Little evidence was found about $\mathrm{Cd}$ in marine systems being impacted by human activities (Macdonald et al. 2000). Lead presence in the Arctic is of concern because of the long-range transport of this metal. Lead has been delivered in large amounts to the Arctic and is thought to mainly come from industrial activities (Pacyna 1995; Macdonald et al. 2000). Even though $\mathrm{Ag}, \mathrm{Cd}$, and $\mathrm{Pb}$ were encountered at low levels, it should be noted that both $\mathrm{Ag}$ and $\mathrm{Cd}$ in feathers, as well as $\mathrm{Pb}$ in the blood, had a tendency to increase between 2013 and 2014. Of course, these data only represent 2 years of sampling and efforts should be made to extend that time frame. Nevertheless, the detection of these elements and the increasing pattern should raise concern about the transport of these metals to the Arctic environment and potential consequences for sensitive species, such as the ivory gull, that are spending their life span in Northern environments. Those species will have to cope with not only the reduction of sea ice cover triggered by climate change but also increasing contaminant loads due to changes in global contaminant pathways and new anthropogenic pressures (Macdonald et al. 2005). Conversely to these metals, As reached relatively high levels in blood samples of ivory gulls. Background As 
concentrations are usually low in living organisms $\left(<1 \mu \mathrm{g} \mathrm{g}^{-1}\right.$ wet weight (ww), approximately 5 $\mu \mathrm{g} \mathrm{g}^{-1} \mathrm{dw}$; Eisler 1988). Reference values for blood As in birds from uncontaminated areas is approximately $0.02 \mu \mathrm{g} \mathrm{g}^{-1} \mathrm{ww}$ (approximately $0.4 \mu \mathrm{g} \mathrm{g}^{-1} \mathrm{dw}$ in red blood cells; Burger and Gochfeld 1997b; Anderson et al. 2010). For the ivory gull, As concentrations in red blood cells and whole blood were well above those levels, reaching $3.98 \pm 1.45 \mu \mathrm{g} \mathrm{g}^{-1} \mathrm{dw}$ and $5.27 \pm 0.60 \mu \mathrm{g} \mathrm{g}^{-1}$ dw, in 2012 for the whole blood and 2013 for red blood cells, respectively. Arsenic may act as an endocrine disruptor, impair reproduction, trigger sublethal effects or even induce individuals' death in acute cases of As poisoning (Eisler 1994; Kunito et al. 2008). Nevertheless, this element is considered mainly toxic under its inorganic form. In marine biota, As mainly occurs as arsenobetaine, a water soluble organoarsenical that poses little risk to organisms or their consumers. Some ivory gulls specialise on scavenging remains of polar bear kills, whereas others feed on polar cod and crustaceans associated with the ice edge. The importance of polar cods to the diet of ivory gulls has been documented (Divoky 1976; Mehlum 1990; Mehlum and Gabrielsen 1993; Karnovsky et al. 2009). Sele et al. (2015) studied lipid-and water-soluble As species in livers of Northeast Arctic cods (Gadus morhua). Cods with high total As concentrations contained 3 to 7 $\%$ of the total As in the lipid-soluble fraction containing several arsenolipids. Arsenic was therefore mainly present in the water-soluble fraction as arsenobetaine. In contrast, cods displaying low As concentrations contained up to $50 \%$ of the total As as lipid-soluble species. Knowledge about lipid-soluble species is still limited in terms of distribution, metabolism, and also toxicity. Nevertheless, it is very much probable that ivory gulls mainly ingest As under its arsenobetaine form when feeding on polar cods, therefore implying little toxicity for the birds. Overall, it appears however evident that the cumulative and synergetic effects of trace elements, associated with already high organic contaminant levels previously recorded, could be detrimental to this endangered species (Braune et al. 2006; Lucia et al. 2015).

\section{Relationship between trophic position, feeding habitat and trace element concentrations}

Food is the main pathway of contaminant exposure for seabirds. Ivory gulls tend to occupy a high trophic position in the Arctic food web year-round and, consequently, are exposed to high contaminant levels, especially through biomagnification processes (Hobson and Bond 2012). Stable isotope analyses have become a powerful tool to study dietary exposure and biomagnification of contaminants in free-ranging animal populations (Jardine et al. 2006). In the 
present study, both nitrogen and carbon values of birds were positively correlated to $\mathrm{Hg}$ concentrations in most of the tissues. Ivory gulls feeding at higher trophic position, and on more inshore prey enriched in ${ }^{13} \mathrm{C}$ were more likely to display high $\mathrm{Hg}$ exposure and concentrations. The current study demonstrated that individual differences in trophic behaviour triggered discrepancies in $\mathrm{Hg}$ concentrations and the potential biomagnifying ability of this metal in the ivory gull's food web. Mercury under its methylated form is indeed well known for its ability to biomagnify in the Arctic pelagic food web (Ruus et al. 2015). Conversely, Ni and Se concentrations, in feathers and whole blood, respectively, demonstrated negative relationships with $\delta^{15} \mathrm{~N}$. Such relationships have been previously demonstrated for $\mathrm{Ni}$ in the muscle of seabirds (Campbell et al. 2005). Biomagnification of Se, however, has been reported by some authors (Lemly 1999; Muscatello and Janz 2009), whereas others reported no relationship with trophic position (Barceloux 1999; Campbell et al. 2005; Lucia et al. 2013). Results of the present study tend to indicate trophically decreasing Se concentrations along the ivory gull's food web.

Stable carbon values $\left(\delta^{13} \mathrm{C}\right)$ vary little along the food chain. In the marine environment, $\delta^{13} \mathrm{C}$ values are mainly used to determine foraging habitats of predators (Rubenstein and Hobson 2004). Carbon values of ivory gulls were negatively correlated to several elements, including $\mathrm{Cd}, \mathrm{Cu}$, and $\mathrm{Pb}$ in red blood cells, as well as Ag in feathers. This result highlighted that birds feeding on prey enriched in ${ }^{13} \mathrm{C}$ were consequently less likely to have high $\mathrm{Ag}, \mathrm{Cd}, \mathrm{Cu}$, and $\mathrm{Pb}$ concentrations. The inverse pattern has been observed for Fe and Se in red blood cells.

Finally, most of the colonies sampled showed similar stable isotope values and trace element levels, especially in feathers, which are a record of exposure during their formation. This pattern could be explained by two main factors. First, birds from Barentsøya are coming from large areas and travel wide distances to reach their breeding sites. These birds can consequently, at their arrival on their breeding ground, mix between themselves, which would partly explain similarities between colonies, especially in feathers. Conversely, this mixing is creating individual differences in isotopic values and trace element levels within each colony. Second, colonies sampled on Barentsøya are geographically close to each other. Distances are limited and birds from those colonies are most probably using similar feeding grounds around the island and along the ice edge. Nevertheless, it should be noted that birds from the Sigden colony, even if individual variability occurred, showed a tendency of higher $\mathrm{Cu}$ and $\mathrm{Pb}$ concentrations in red blood cells compared with other colonies. 
A previous study on the ivory gull found that birds from Sigden displayed significantly different isotopic values in red blood cells compared with other colonies on Barentsøya (Lucia et al. 2016). Birds from Sigden had lower $\delta^{13} \mathrm{C}$ values. As stated, $\mathrm{Cu}$ concentrations were negatively linked to $\delta^{13} \mathrm{C}$ values. The trophic behaviour of Sigden birds might explain contaminant variability found in

this study. This result should be considered with caution and may be a snapshot of contaminant exposure and trophic behaviour during an episodic event (e.g., climatic event, poor sea-ice conditions). More data are needed to envision whether differences persist in time in the context of a changing Arctic environment.

\section{Conclusion}

The most quantitatively abundant, non-essential trace element found in the ivory gull was $\mathrm{Hg}$. In blood samples, Se was present in a substantial surplus compared to Hg. Even though ivory gulls were presumably protected against $\mathrm{Hg}$ toxicity, this study raised concern about Se toxicity in this sensitive species. Moreover, other trace elements were detected, such as $\mathrm{Ag}, \mathrm{As}, \mathrm{Cd}$, and $\mathrm{Pb}$, which would warrant monitoring because of their potential additive/synergetic effects. The current study demonstrated both individual differences in trophic behaviour that triggered discrepancies in $\mathrm{Hg}$ concentrations, and the biomagnifying ability of this metal in the ivory gull's food web. This study also highlighted the mixing of birds coming from different geographical areas on Barentsøya, which would partly explain similarities between colonies in terms of isotopic values, trace element levels, and overall individual variability within each colony. Finally, more data are needed to understand fully the ivory gull's trophic behaviour and its link with trace element levels, especially in the context of a changing environment.

Acknowledgments. Funding was provided by Seventh Framework Programme (Grant no. 622019). The authors thank the European Commission for its financial support through a Marie Curie fellowship to M. Lucia, as well as Gael Guillou from the plateforme "Analyses Isotopiques" of LIENSs for technical support during isotopic analyses. We thank Carine Churlaud and Maud Brault-Favrou from the plateforme "Analyses Elémentaires" of LIENSs for their assistance with chemical analyses. The CPER (Contrat de Projet Etat-Région) is acknowledged for the funding of the ICP and AMA. The fieldwork was supported by the Norwegian Polar Institute's centre for Ice, Climate and Ecosystems (ICE), and the SEAPOP program (seapop. no). Thanks to Vidar Bakken, Audun Igesund, Cecilie Miljeteig, Knut Olsen, Maria Gavrilo, Olivier Gilg, and Odd Kindberg for help in the field. 


\section{References}

Anderson MJ, Gorley RN, Clarke KR (2008) PERMANOVA + for PRIMER: Guide to software and statistical methods. PRIMER-E Ltd, Plymouth

Anderson ORJ, Phillips RA, Shore RF, McGill RAR, McDonald RA, Bearhop S (2010) Element patterns in albatrosses and petrels: Influence of trophic position, foraging range, and prey type. Environ Pollut 158:98-107

Arctic Monitoring and Assessment Programme (1997) Arctic pollution Issues: A state os the Arctic Environment report. AMAP, Oslo

Arctic Monitoring and Assessment Programme (2011) AMAP Assessment 2011: Mercury in the Arctic. AMAP, Oslo

Barceloux DG (1999) Selenium. Clin Toxicol 37:145-172

Bond AL, Hobson KA, Branfireun BA (2015) Rapidly increasing methyl mercury in endangered ivory gull (Pagophila eburnea) feathers over a 130 year record. Proc R Soc B 282:20150032

Braune BM, Mallory ML, Gilchrist HG (2006) Elevated mercury levels in a declining population of ivory gulls in the Canadian Arctic. Mar Pollut Bull 52:969-987

Braune BM, Mallory ML, Gilchrist HG, Letcher RJ, Drouillard KG (2007) Levels and trends of organochlorines and brominated flame retardants in Ivory Gull eggs from the Canadian Arctic, 1976 to 2004. Sci Total Environ 378:403-417

Braune BM, Scheuhammer AM (2008) Trace element and metallothionein concentrations in seabirds from the Canadian Arctic. Environ Toxicol Chem 27:645-651

Burger J, Gochfeld M (1997) Age differences in metals in the blood of herring (Larus argentatus) and Franklin's (Larus pipixcan) gulls. Arch Environ Contam and Toxicol 33:436-440

Burgess NM, Meyer MW (2008) Methylmercury exposure associated with reduced productivity in common loons. Ecotoxicology 17:83-91

Campbell LM, Norstrom RJ, Hobson KA, Muir DCG, Backus S, Fisk AT (2005) Mercury and other trace elements in a pelagic Arctic marine food web (Northwater Polynya, Baffin Bay). Sci Total Environ 351-352:247-263

Clarke KR, Gorley RN (2006) PRIMER v6: User manual/Tutorial. PRIMER-E Ltd, Plymouth Divoky GJ (1976) The pelagic feeding habits of ivory and Ross' gulls. Condor 78:85-90 
Eisler R (1988) Arsenic hazards to fish, wildlife, and invertebrates: A synoptic review. Contaminant Hazard Reviews Report No. 12, U.S. Department of the Interior, Fish and Wildlife Service, Biological Report 85(1.12)

Eisler RA (1994) A review of arsenic hazards to plants and animals with emphasis on fishery and wildlife resources. In: Nriagu JO (ed) Arsenic in the environment, part II: human health and ecosystem effects. Wiley, New York, pp 185-259

Gibson LA, Lavoie RA, Bissegger S, Campbell LM, Langlois VS (2014) A positive correlation between mercury and oxidative stress-related gene expression (GPX3 and GSTM3) is measured in female Double-crested Cormorant blood. Ecotoxicology 23:1004-1014

Gilg O, Strøm H, Aebischer A, Gavrilo MV, Volkov AE, Miljeteig C, Sabard B (2010) Postbreeding movements of northeast Atlantic ivory gull Pagophila eburnea populations. J Avian Biol 41:532-542

Goutte A, Barbraud C, Meillère A, Carravieri A, Bustamante P, Labadie P, Budzinski H, Delord K, Cherel Y, Weimeskirch H, Chastel O (2014a) Demographic consequences of heavy metals and persistent organic pollutants in a vulnerable long-lived bird, the wandering albatross. Proc R Soc B 281:20133313

Goutte A, Bustamante P, Barbraud C, Delord K, Weimeskirch H, Chastel O (2014b) Demographic responses to mercury exposure in two closely-related Antarctic top predators. Ecology 95:1075-1086

Gilchrist HG, Mallory ML (2005) Declines in abundance and distribution of the ivory gull (Pagophila eburnea) in Arctic Canada. Biol Cons 121:303-309

Hobson KA, Bond AL (2012) Extending an indicator: year-round information on seabird trophic ecology from multiple-tissue stable-isotope analyses. Mar Ecol Prog Ser 461:233-243

Hobson KA, Fisk A, Karnovsky N, Holst M, Gagnon JM, Fortier M (2002) A stable isotope $\left(\delta^{13}\right.$ C, $\delta^{15} \mathrm{~N}$ ) model for the North Water food web: implications for evaluating trophodynamics and the flow of energy and contaminants. Deep-Sea Res II 49:5131-5150

Hoffman DJ (2002) Role of selenium toxicity and oxidative stress in aquatic birds. Aquat Toxicol $57: 11-26$

Howell SNG (2001) Molt of the Ivory Gull. Waterbirds 24:438-442 
Ikemoto T, Kunito T, Tanaka H, Baba N, Miyazaki N, Tanabe S (2004) Detoxification mechanism of heavy metals in marine mammals and seabirds: interaction of selenium with mercury, silver, copper, zinc, and cadmium in liver. Arch Environ Contam Toxicol 47:402-413

Jardine TD, Kidd KA, Fisk AT (2006) Applications, considerations, and sources of uncertainty when using stable isotope analysis in ecotoxicology. Environ Sci Technol 40:7501-7511

Karnovsky NJ, Hobson KA, Brown ZW, Hunt GL Jr (2009) Distribution and diet of ivory gulls (Pagophila eburnea) in the North Water Polynya. Arctic 62:65-74

Khan MAK, Wang F (2009) Mercury-selenium compounds and their toxicological significance: towards a molecular understanding of the mercury-selenium antagonism. Environ Toxicol Chem 28:1567-1577

Kunito T, Kubota R, Fujihara J, Agusa T, Tanabe S (2008) Arsenic in marine mammals, seabirds, and sea turtles. Rev Environ Contam Toxicol 195:31-69

Lemly A (1999) Selenium transport and bioaccumulation in aquatic systems: a proposal for water quality criteria based on hydrological units. Ecotoxicol Environ Saf 42:150-156

Lucia M, Bocher P, Chambosse M, Delaporte P, Bustamante P (2013) Trace element accumulation in relation to trophic niches of shorebirds using intertidal mudflats. J Sea Res 92:134-143

Lucia M, Strøm H, Bustamante P, Herzke D, Gabrielsen GW (2016) Contamination of ivory gulls (Pagophila eburnea) at four colonies in Svalbard in relation to their trophic behavior. Polar Biol: doi 10.1007/s00300-016-2018-7

Lucia M, Verboven N, Strøm H, Miljeteig C, Gavrilo MV, Braune BM, Boertmann D, Gabrielsen GW (2015) Circumpolar contamination in eggs of the high-Arctic ivory gull Pagophila eburnea. Environ Toxicol Chem 34:1552-1561

Macdonald RW, Barrie LA, Bidleman TF, Diamond ML, Gregor DJ, Semkin RG, Strachan WMJ, Li YF, Wania F, Alaee M, Alexeeva LB, Backus SM, Bailey R, Bewers JM, Gobeil C, Halsall CJ, Harner T, Hoff JT, Jantunen LMM, Lockhart WL, Mackay D, Muir DCG, Pudykiewicz J, Reimer KJ, Smith JN, Stern GA, Schroeder WH, Wagemann R, Yunker MB (2000) Contaminants in the Canadian Arctic: 5 years of progress in understanding sources, occurrence and pathways. Sci Total Environ 254:93-234

Macdonald RW, Harner T, Fyfe J (2005) Recent climate change in the Arctic and its impact on contaminant pathways and interpretation of temporal trend data. Sci Total Environ 342:5-86 
Mallory ML, Braune BM, Provencher JF, Callaghan DB, Gilchrist HG, Edmonds ST, Allard K, O’Driscoll NJ (2015) Mercury concentrations in feathers of marine birds in Arctic Canada. Mar Poll Bull 98:308-313

Mehlum F (1990) Seabird distribution in the northern Barents Sea marginal ice-zone during late summer. Polar Res 8:61-65

Mehlum F, Gabrielsen GW (1993) The diet of High-Arctic seabirds in coastal and ice-covered, pelagic areas near the Svalbard archipelago. Polar Res 12:1-20

Miljeteig C, Strøm H, Gavrilo MV, Volkov A, Jenssen BM, Gabrielsen GW (2009) High levels of contaminants in ivory gull Pagophila eburnea eggs from the Russian and Norwegian Arctic. Environ Sci Technol 43:5521-5528

Muir D, Braune B, DeMarch B, Norstrom R, Wagemann R, Lockhart L, Hargrave B, Bright D, Addison R, Payne J, Reimer K (1999) Spatial and temporal trends and effects of contaminants in the Canadian Arctic marine ecosystem: A review. Sci Total Environ 230:83-144

Muscatello JR, Janz DM (2009) Selenium accumulation in aquatic biota downstream of a uranium mining and milling operation. Sci Total Environ 407:1318-1325

Øverjordet IB, Gabrielsen GW, Berg T, Ruus A, Evenset A, Borgå K, Christensen G, Lierhagen S, Jenssen BM (2015) Effect of diet, location and sampling year on bioaccumulation of mercury, selenium and cadmium in pelagic feeding seabirds in Svalbard. Chemosphere 122:14-22

Pacyna JM (1995) The origin of Arctic air pollutants: lessons learned and future research. Sci Total Environ 160-161:39-53

Poissant L, Zhang HH, Canario J, Constant P (2008) Critical review of mercury fates and contamination in the arctic tundra ecosystem. Sci Total Environ 400:173-211

Rubenstein DR, Hobson KA (2004) From birds to butterflies: animal movement patterns and stable isotopes. Trends Ecol Evol 19:256-263

Ruus A, Øverjordet IB, Braatem HFV, Evenset A, Christensen G, Heimstad ES, Gabrielsen GW, Borgå K (2015) Methylmercury biomagnification in an Arctic pelagic food web. Environ Toxicol Chem 34:2636-2643

Sele V, Sloth JJ, Julshamn K, Skov K, Amlund H (2015) A study of lipid- and water-soluble arsenic species in liver of Northeast Arctic cod (Gadus morhua) containing high levels of total arsenic. J Trace Elem Med Biol 30:171-179 
Spencer NC, Gilchrist HG, Mallory ML (2014) Annual Movement Patterns of Endangered Ivory Gulls: The Importance of Sea Ice. PLoS ONE 9:e115231

Stewart MS, Spallholz JE, Neldner KH, Pence BC (1999) Selenium compounds have disparate abilities to impose oxidative stress and induce apoptosis. Free Radic Biol Med 26:42-48

Thompson DR, Furness RW (1989) Comparison of the levels of total and organic mercury in seabird feathers. Mar Pollut Bull 20:577-579 


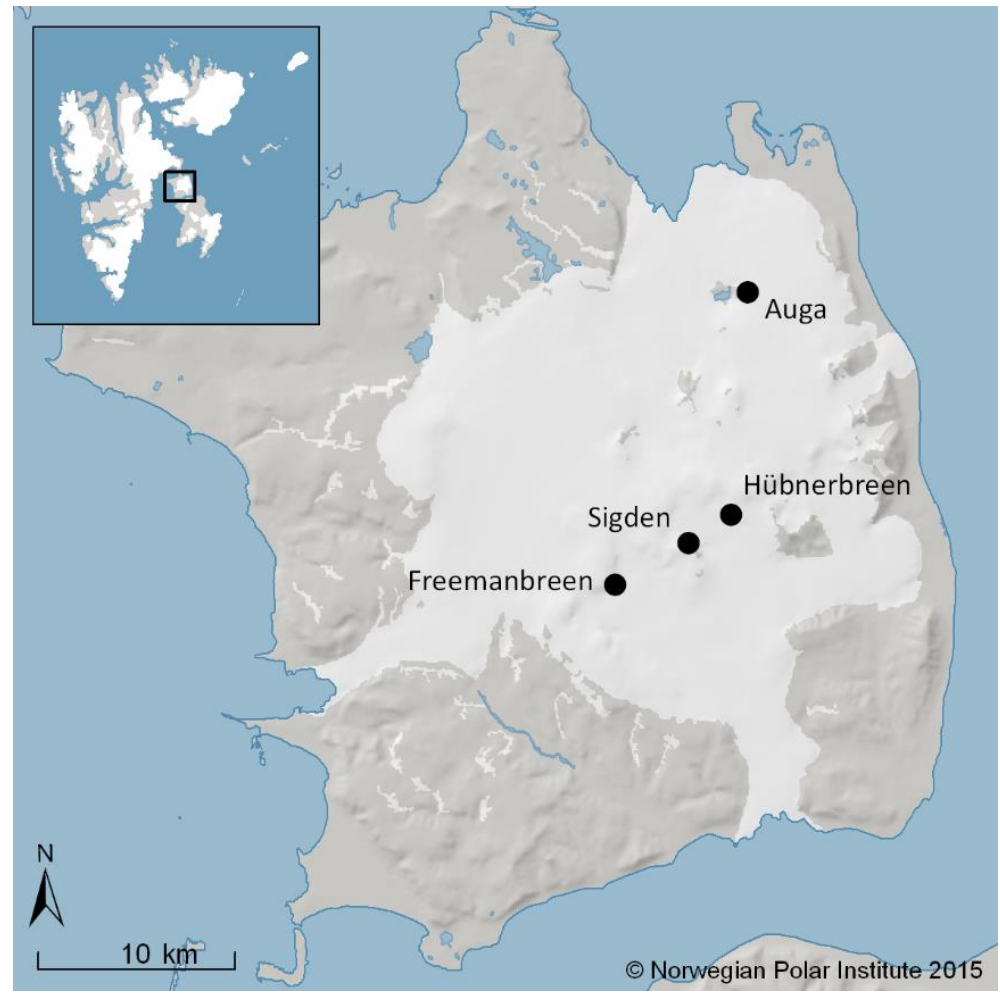

Fig. 1 Locations of four ivory gull (Pagophila eburnea) colonies sampled on Barentsøya ( $78^{\circ} 25^{\prime} \mathrm{N}$, $\left.21^{\circ} 27^{\prime} E\right)$, Svalbard, Norway 
(A)

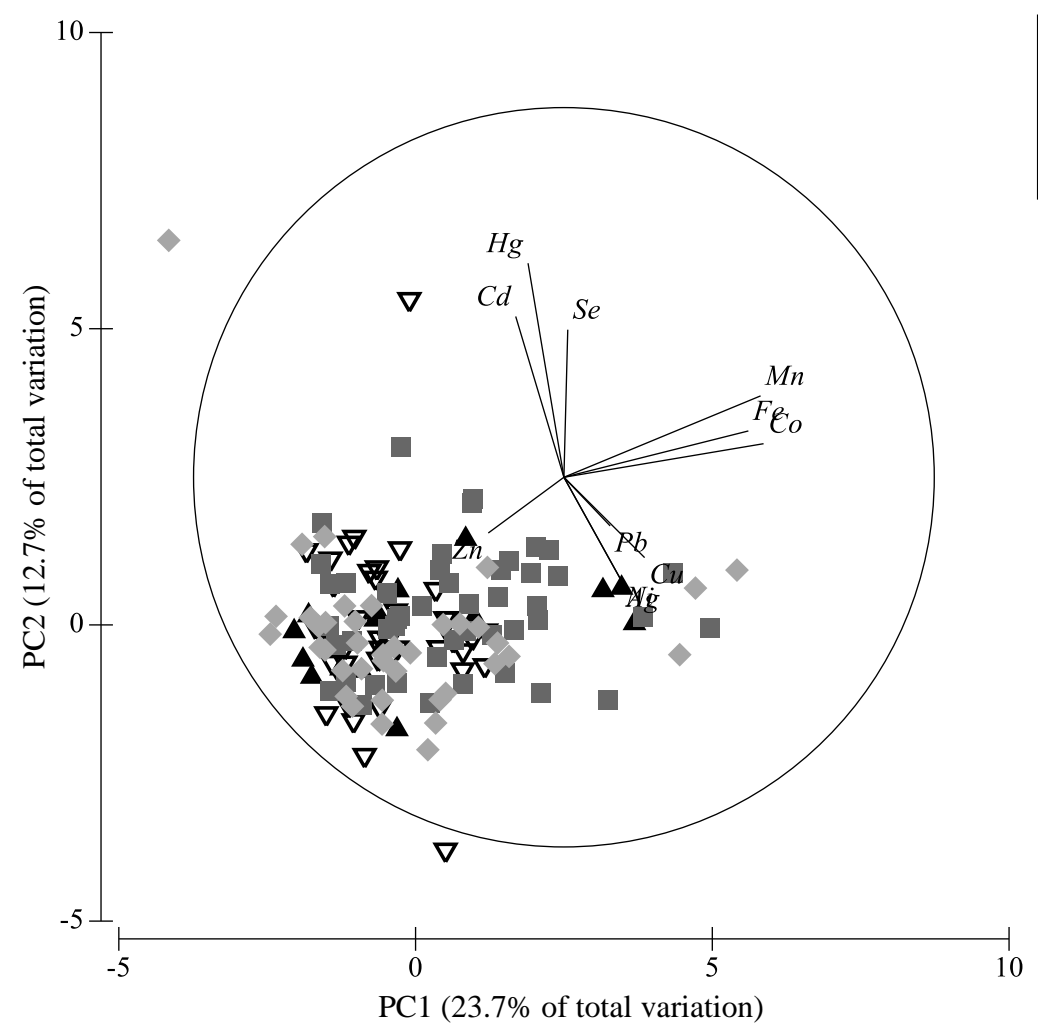

(B)

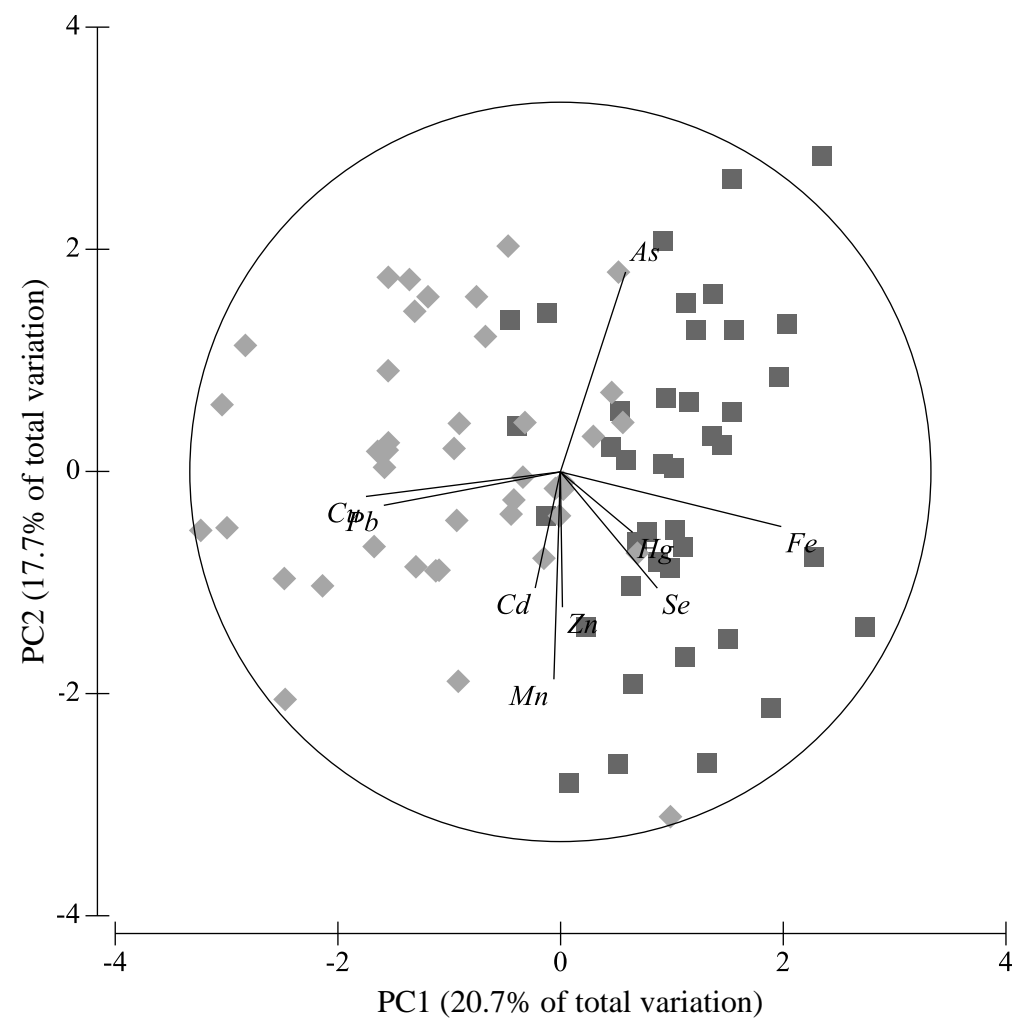

Fig. 2 Principal component analysis based on trace element concentrations in feathers (A), and red blood cells (B) of ivory gulls sampled over several years. For clarity and readability reasons, the center of the correlation circle has been moved on the $\mathrm{A}$ graph from its origin $(\mathrm{X}=0 ; \mathrm{Y}=0)$ 

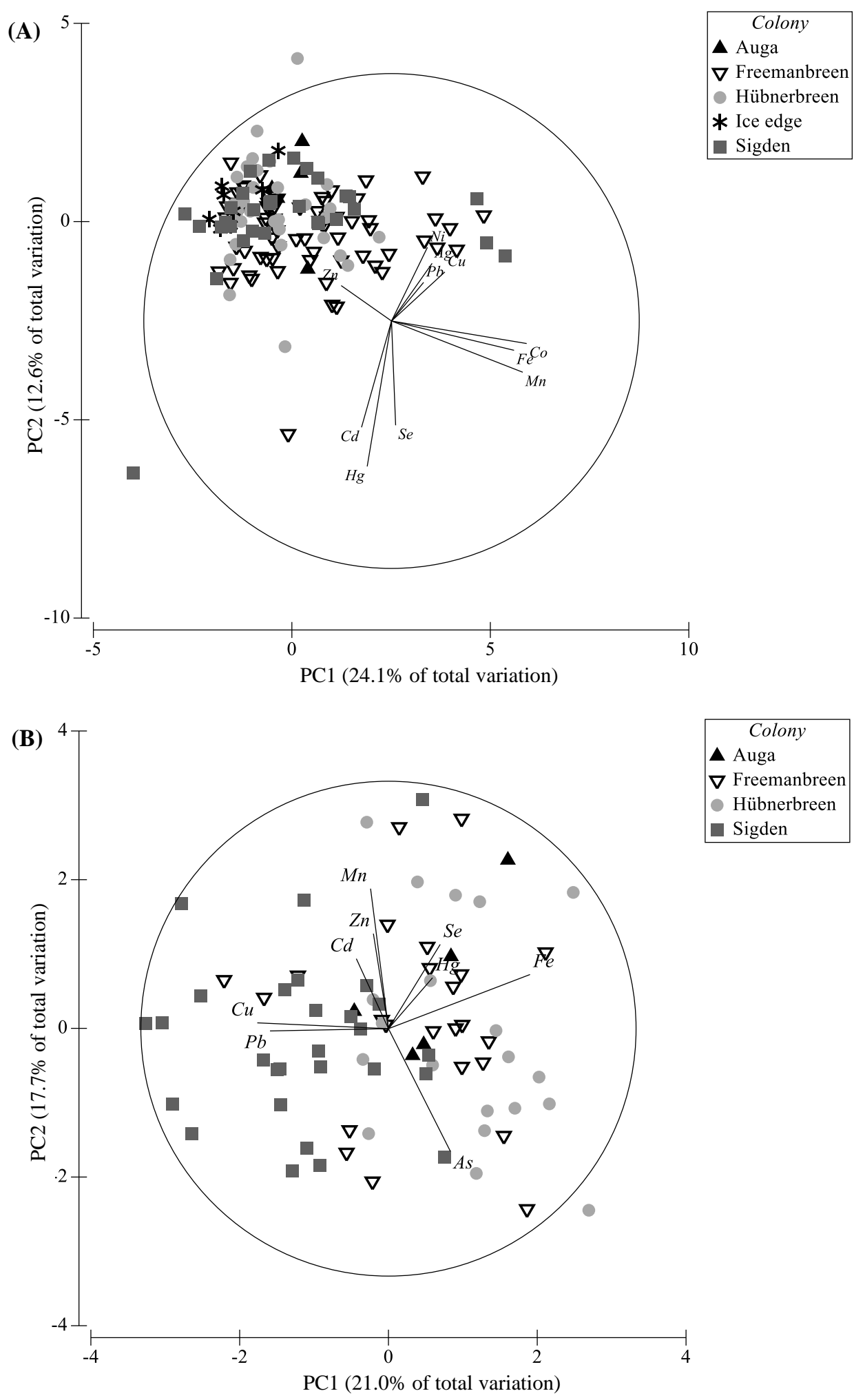

Fig. 3 Principal component analysis based on trace element concentrations in feathers (A), and red blood cells (B) of ivory gulls from four colonies (Auga, Freemanbreen, Hübnerbreen, Sigden) and the ice edge. For clarity and readability reasons, the center of the correlation circle has been moved on the A graph from its origin $(X=0 ; Y=0)$ 

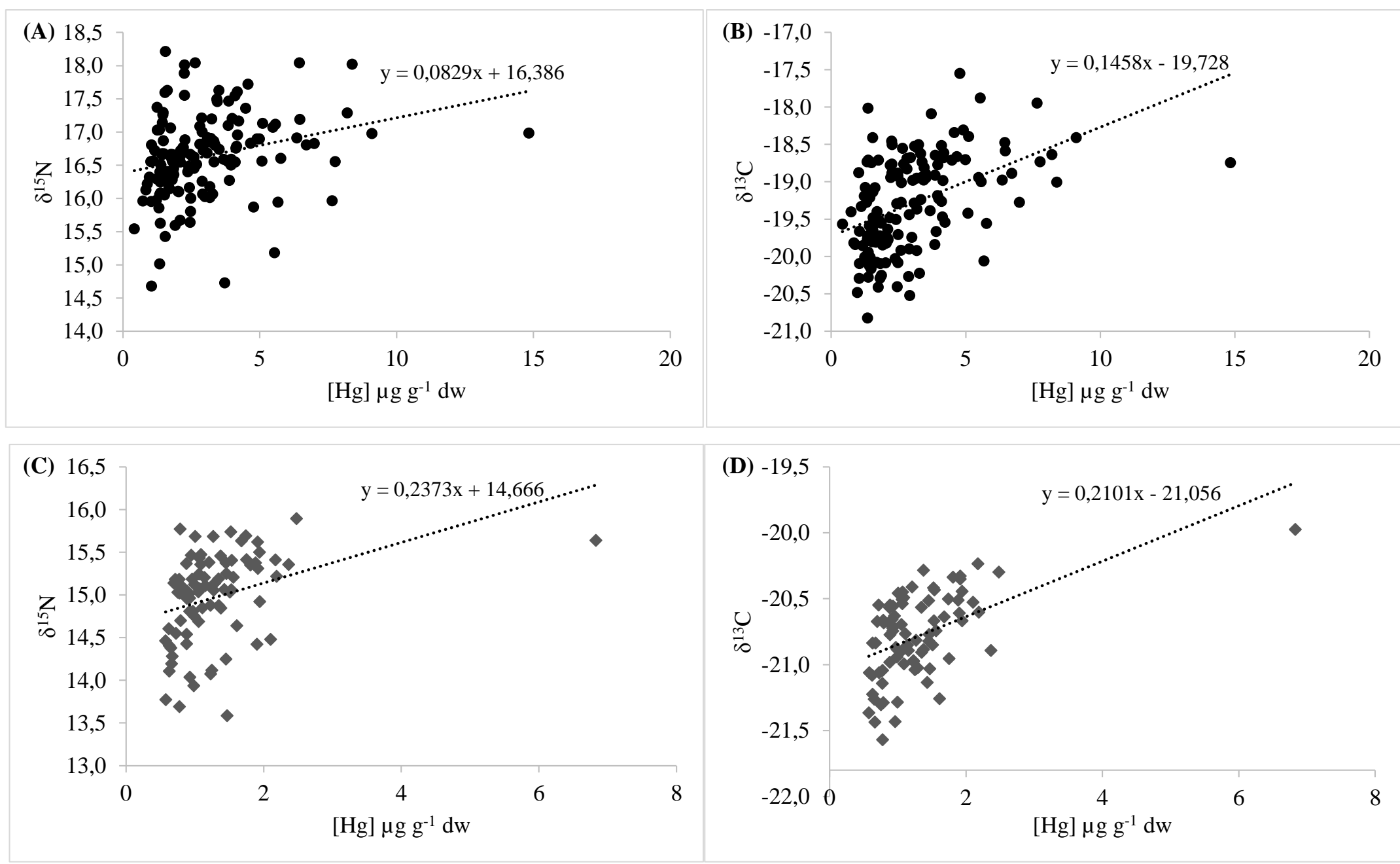


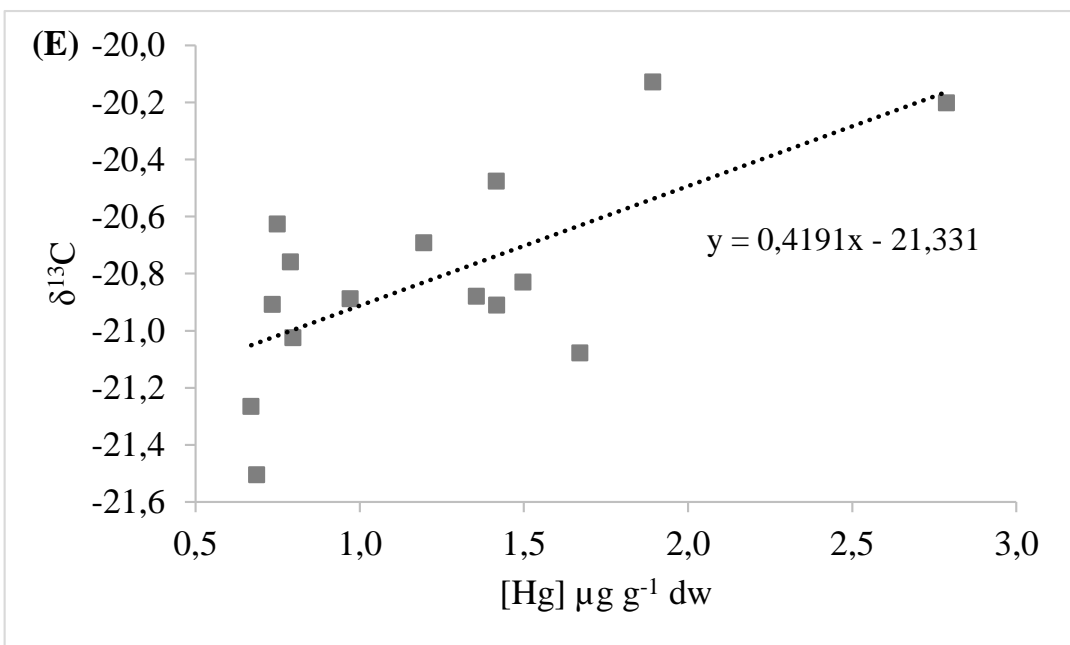

Fig. 4 Significant positive relationships between nitrogen $\left(\delta^{15} \mathrm{~N}\right)$ and carbon $\left(\delta^{13} \mathrm{C}\right)$ isotope values $(\%)$ and Hg concentrations $\left(\mu \mathrm{g} \mathrm{g}^{-1}\right)$ in feathers (A, B), red blood cells (C, D), and whole blood (E) of the ivory gull 
Table 1 Concentrations (Mean $\pm \mathrm{SD}$, range; $\mu \mathrm{g} \mathrm{g} \mathrm{g}^{-1} \mathrm{dw}$ ) of non-essential trace elements in tissues of the ivory gull (Pagophila eburnea) from Barentsøya (Svalbard) in 2011, 2012, 2013, 2014

\begin{tabular}{|c|c|c|c|c|c|c|c|c|c|}
\hline \multirow[t]{2}{*}{ Element } & \multicolumn{4}{|l|}{ Feathers } & \multicolumn{3}{|l|}{ Whole blood } & \multicolumn{2}{|l|}{ Red blood cells } \\
\hline & $\begin{array}{l}2011 \\
n=19\end{array}$ & $\begin{array}{l}2012 \\
n=40\end{array}$ & $\begin{array}{l}2013 \\
n=47\end{array}$ & $\begin{array}{l}2014 \\
n=39\end{array}$ & $\begin{array}{l}2011 \\
n=6\end{array}$ & $\begin{array}{l}2012 \\
n=4\end{array}$ & $\begin{array}{l}2013 \\
n=5\end{array}$ & $\begin{array}{l}2013 \\
n=40\end{array}$ & $\begin{array}{l}2014 \\
n=42\end{array}$ \\
\hline \multirow[t]{2}{*}{$\mathrm{Ag}$} & $0.052 \pm 0.003^{\mathrm{a}}$ & $0.048 \pm 0.002^{\mathrm{a}}$ & $0.066 \pm 0.003^{\mathrm{b}}$ & $0.066 \pm 0.003^{\mathrm{b}}$ & nd & nd & nd & nd & nd \\
\hline & $0.033-0.080$ & $<0.030-0.084$ & $<0.040-0.139$ & $<0.030-0.103$ & nd & nd & nd & nd & nd \\
\hline \multirow[t]{2}{*}{$\mathrm{Cd}$} & $0.045 \pm 0.005^{\mathrm{ac}}$ & $0.028 \pm 0.003^{\mathrm{b}}$ & $0.045 \pm 0.003^{\mathrm{a}}$ & $0.087 \pm 0.030^{\mathrm{c}}$ & $0.113 \pm 0.018$ & nd & nd & $0.010 \pm 0.001^{\mathrm{a}}$ & $0.016 \pm 0.001^{\mathrm{b}}$ \\
\hline & $<0.020-0.095$ & $<0.020-0.093$ & $<0.020-0.116$ & $<0.020-1.199$ & $<0.010-0.177$ & nd & nd & $<0.010-0.021$ & $<0.010-0.037$ \\
\hline \multirow[t]{2}{*}{$\mathrm{Hg}$} & $2.65 \pm 0.42^{\mathrm{a}}$ & $3.03 \pm 0.41^{\mathrm{a}}$ & $2.79 \pm 0.24^{\mathrm{a}}$ & $3.39 \pm 0.30^{\mathrm{a}}$ & $1.68 \pm 0.27^{\mathrm{a}}$ & $0.81 \pm 0.05^{\mathrm{b}}$ & $1.06 \pm 0.16^{\mathrm{b}}$ & $1.39 \pm 0.16$ & $1.20 \pm 0.07$ \\
\hline & $0.41-6.46$ & $0.84-14.8$ & $0.89-8.38$ & $0.97-9.10$ & $0.80-2.79$ & $0.73-0.97$ & $0.67-1.36$ & $0.63-6.83$ & $0.57-2.37$ \\
\hline \multirow[t]{2}{*}{$\mathrm{Pb}$} & $0.08 \pm 0.01^{\mathrm{a}}$ & $0.13 \pm 0.01^{\mathrm{bc}}$ & $0.10 \pm 0.01^{\mathrm{c}}$ & $0.13 \pm 0.02^{\mathrm{b}}$ & $0.02 \pm 0.01^{\mathrm{a}}$ & $0.02 \pm 0.01^{\mathrm{a}}$ & $0.07 \pm 0.04^{\mathrm{a}}$ & $0.03 \pm 0.004^{\mathrm{a}}$ & $0.70 \pm 0.13^{\mathrm{b}}$ \\
\hline & $0.04-0.22$ & $0.07-0.37$ & $0.04-0.28$ & $<0.03-0.53$ & $<0.01-0.06$ & $<0.02-0.03$ & $<0.02-0.22$ & $<0.01-0.10$ & $<0.01-3.79$ \\
\hline
\end{tabular}

nd: values below the detection limit

Significant differences between years for each trace element and tissue distinctly are indicated by letters at the level $\alpha=0.05$ (MannWhitney U-test) 
Table 2 Concentrations (Mean $\pm \mathrm{SD}$, range; $\mu \mathrm{g} \mathrm{g}^{-1} \mathrm{dw}$ ) of essential trace elements in tissues of the ivory gull (Pagophila eburnea) from Barentsøya, Svalbard, in 2011, 2012, 2013, 2014

\begin{tabular}{|c|c|c|c|c|c|c|c|c|c|}
\hline \multirow[t]{2}{*}{ Element } & \multicolumn{4}{|l|}{ Feathers } & \multicolumn{3}{|l|}{ Whole blood } & \multicolumn{2}{|c|}{ Red blood cells } \\
\hline & $\begin{array}{l}2011 \\
n=19\end{array}$ & $\begin{array}{l}2012 \\
n=40\end{array}$ & $\begin{array}{l}2013 \\
n=47\end{array}$ & $\begin{array}{l}2014 \\
n=39\end{array}$ & $\begin{array}{l}2011 \\
n=6\end{array}$ & $\begin{array}{l}2012 \\
n=4\end{array}$ & $\begin{array}{l}2013 \\
n=5\end{array}$ & $\begin{array}{l}2013 \\
n=40\end{array}$ & $\begin{array}{l}2014 \\
n=42\end{array}$ \\
\hline \multirow[t]{2}{*}{ As } & nd & nd & nd & nd & $3.76 \pm 0.56^{\mathrm{a}}$ & $3.98 \pm 1.45^{\mathrm{a}}$ & $3.83 \pm 0.98^{\mathrm{a}}$ & $5.27 \pm 0.60^{\mathrm{a}}$ & $4.80 \pm 0.36^{\mathrm{a}}$ \\
\hline & nd & nd & nd & nd & $2.34-5.71$ & $1.48-7.38$ & $1.14-6.70$ & $0.84-19.0$ & $1.66-10.7$ \\
\hline \multirow[t]{2}{*}{ Co } & $0.02 \pm 0.002^{\mathrm{a}}$ & $0.01 \pm 0.001^{\mathrm{a}}$ & $0.02 \pm 0.001^{\mathrm{a}}$ & $0.02 \pm 0.002^{\mathrm{a}}$ & nd & $0.01 \pm 0.004$ & nd & nd & nd \\
\hline & $<0.02-0.04$ & $<0.02-0.02$ & $<0.02-0.04$ & $<0.01-0.06$ & $<0.02-0.01$ & $<0.02-0.02$ & $<0.02-0.03$ & $<0.01-0.01$ & $<0.01-0.03$ \\
\hline \multirow[t]{2}{*}{$\mathrm{Cr}$} & nd & nd & nd & nd & nd & nd & nd & nd & $0.14 \pm 0.02$ \\
\hline & nd & nd & nd & nd & nd & nd & nd & $<0.1-1.14$ & $<0.1-0.27$ \\
\hline \multirow[t]{2}{*}{$\mathrm{Cu}$} & $16.5 \pm 0.39^{\mathrm{a}}$ & $16.7 \pm 0.29^{\mathrm{a}}$ & $17.3 \pm 0.28^{\mathrm{ab}}$ & $17.9 \pm 0.35^{\mathrm{b}}$ & $1.21 \pm 0.05^{\mathrm{a}}$ & $1.09 \pm 0.03^{\mathrm{a}}$ & $1.13 \pm 0.03^{\mathrm{a}}$ & $0.99 \pm 0.02^{\mathrm{a}}$ & $1.11 \pm 0.02^{\mathrm{b}}$ \\
\hline & $13.5-20.8$ & $12.9-21.6$ & $13.1-20.9$ & $13.8-23.7$ & $1.04-1.31$ & $1.03-1.16$ & $1.05-1.20$ & $0.85-1.29$ & $0.92-1.53$ \\
\hline \multirow[t]{2}{*}{$\mathrm{Fe}$} & $13.0 \pm 2.53^{\mathrm{abc}}$ & $7.89 \pm 0.75^{\mathrm{a}}$ & $16.2 \pm 1.31^{\mathrm{b}}$ & $8.38 \pm 1.34^{\mathrm{c}}$ & $2025 \pm 19^{\mathrm{a}}$ & $2108 \pm 31^{\mathrm{a}}$ & $2037 \pm 24^{\mathrm{a}}$ & $2585 \pm 9^{\mathrm{a}}$ & $2419 \pm 14^{\mathrm{b}}$ \\
\hline & $<5.45-40.5$ & $<6.70-27.6$ & $<6.60-50.6$ & $<5.10-49.8$ & 1950-2075 & $2020-2162$ & 1965-2088 & $2460-2708$ & $2259-2588$ \\
\hline \multirow[t]{2}{*}{$\mathrm{Mn}$} & $0.57 \pm 0.14^{\mathrm{a}}$ & $0.68 \pm 0.06^{\mathrm{ab}}$ & $0.86 \pm 0.07^{\mathrm{b}}$ & $0.60 \pm 0.09^{\mathrm{a}}$ & $0.08 \pm 0.004^{\mathrm{a}}$ & $0.23 \pm 0.12^{\mathrm{a}}$ & $0.13 \pm 0.03^{\mathrm{a}}$ & $0.14 \pm 0.01^{\mathrm{a}}$ & $0.13 \pm 0.01^{\mathrm{a}}$ \\
\hline & $0.03-1.87$ & $0.23-1.87$ & $0.24-1.94$ & $0.04-2.43$ & $0.06-0.09$ & $0.08-0.59$ & $0.08-0.22$ & $0.09-0.24$ & $0.08-0.22$ \\
\hline \multirow[t]{2}{*}{$\mathrm{Ni}$} & $0.09 \pm 0.01^{\mathrm{ab}}$ & $0.08 \pm 0.01^{\mathrm{a}}$ & $0.08 \pm 0.01^{\mathrm{b}}$ & $0.08 \pm 0.01^{\mathrm{ab}}$ & nd & nd & nd & nd & nd \\
\hline & $<0.07-0.28$ & $<0.07-0.16$ & $<0.05-0.21$ & $<0.05-0.13$ & nd & nd & nd & nd & nd \\
\hline \multirow[t]{2}{*}{$\mathrm{Se}$} & $1.12 \pm 0.04^{\mathrm{a}}$ & $1.20 \pm 0.05^{\mathrm{ab}}$ & $1.38 \pm 0.06^{\mathrm{b}}$ & $1.16 \pm 0.03^{\mathrm{a}}$ & $34.4 \pm 7.7^{\mathrm{a}}$ & $15.1 \pm 0.4^{\mathrm{b}}$ & $25.8 \pm 4.2^{\mathrm{ab}}$ & $25.5 \pm 1.5^{\mathrm{a}}$ & $22.6 \pm 1.3^{\mathrm{a}}$ \\
\hline & $0.96-1.46$ & $<0.99-2.13$ & $<1.58-3.49$ & $<1.05-1.55$ & $17.5-59.2$ & $14.1-15.8$ & $13.1-37.6$ & $12.8-51.7$ & $9.7-44.2$ \\
\hline \multirow[t]{2}{*}{ V } & nd & nd & nd & nd & nd & nd & nd & nd & nd \\
\hline & nd & nd & nd & nd & nd & nd & nd & nd & nd \\
\hline \multirow[t]{2}{*}{$\mathrm{Zn}$} & $102.4 \pm 1.8^{\mathrm{a}}$ & $104.7 \pm 1.5^{\mathrm{ab}}$ & $101.4 \pm 1.4^{\mathrm{a}}$ & $109.2 \pm 1.8^{\mathrm{b}}$ & $26.0 \pm 1.0^{\mathrm{a}}$ & $22.8 \pm 1.4^{\mathrm{ab}}$ & $23.0 \pm 0.6^{\mathrm{b}}$ & $21.6 \pm 0.3^{\mathrm{a}}$ & $21.2 \pm 0.3^{\mathrm{a}}$ \\
\hline & $83.5-117.3$ & $86.4-126.0$ & $78.6-131.9$ & $79.9-140.5$ & $23.1-30.1$ & $21.1-27.0$ & $21.7-24.8$ & $18.5-25.4$ & $18.1-24.0$ \\
\hline
\end{tabular}

nd: between $60 \%$ and $100 \%$ of the values were below the quantification limit, therefore, no means were calculated. When all values were below the quantification limit, "nd" was also indicated in range boxes

Significant differences between years for each trace element and tissue distinctly are indicated by letters at the level $\alpha=0.05$ (Mann-Whitney U-test) 
Table 3 Correlation between trace elements in feathers, whole blood, and red blood cells of the ivory gull ( $p<0.05$; Spearman correlation test)

\begin{tabular}{llll}
\hline Elements & Feathers & Whole blood & Red blood cells \\
\hline $\mathrm{Ag}$ & $+\mathrm{Cd},+\mathrm{Cu}$ & $-\mathrm{Pb}$ & $-\mathrm{Mn},-\mathrm{Pb}$ \\
$\mathrm{As}$ & & & $+\mathrm{Cu},-\mathrm{Fe}$ \\
$\mathrm{Cd}$ & $+\mathrm{Ag},+\mathrm{Hg},+\mathrm{Se}$ & & \\
$\mathrm{Co}$ & $+\mathrm{Cu},+\mathrm{Fe},+\mathrm{Mn},+\mathrm{Ni},+\mathrm{Pb},-\mathrm{Zn}$ & & $+\mathrm{Cd},-\mathrm{Fe},+\mathrm{Pb}$ \\
$\mathrm{Cr}$ & $+\mathrm{Ag},+\mathrm{Co},+\mathrm{Fe},+\mathrm{Mn},+\mathrm{Se}$ & $+\mathrm{Pb}$ & $-\mathrm{Cd},-\mathrm{Cu},-\mathrm{Pb},+\mathrm{Se}$ \\
$\mathrm{Cu}$ & $+\mathrm{Co},+\mathrm{Cu},+\mathrm{Mn},-\mathrm{Zn}$ & $+\mathrm{Zn}$ & $+\mathrm{Se}$ \\
$\mathrm{Fe}$ & $+\mathrm{Cd},-\mathrm{Ni},+\mathrm{Se}$ & & $-\mathrm{As}$ \\
$\mathrm{Hg}$ & $+\mathrm{Co},+\mathrm{Cu},+\mathrm{Fe},+\mathrm{Ni},+\mathrm{Pb},-\mathrm{Zn}$ & $-\mathrm{As},+\mathrm{Fe}$ & $-\mathrm{As},+\mathrm{Cu},-\mathrm{Fe}$ \\
$\mathrm{Mn}$ & $+\mathrm{Co},-\mathrm{Hg},+\mathrm{Mn},-\mathrm{Zn}$ & & $+\mathrm{Fe},+\mathrm{Hg}$ \\
$\mathrm{Ni}$ & $+\mathrm{Co},+\mathrm{Mn}$ & $+\mathrm{Hg}$ & \\
$\mathrm{Pb}$ & $+\mathrm{Cd},+\mathrm{Cu},+\mathrm{Hg}$ & & \\
$\mathrm{Se}$ & $-\mathrm{Co},-\mathrm{Fe},-\mathrm{Mn},-\mathrm{Ni}$ & & \\
$\mathrm{Zn}$ & &
\end{tabular}

